\title{
Effect of chemical mutagens on growth of Okra (Abelmoschus esculentus L. Moench)
}

\author{
Mir Muhammad Nizamani ${ }^{1,2}$, Muhammad Rafiq ${ }^{1 *}$, Nazo Noor-ul- \\ Ain ${ }^{1}$, Syed Habib Ahmed Naqvi ${ }^{1}$, Arif Hussain Kaleri ${ }^{2}$ and Juma Gul ${ }^{3}$ \\ 1. Institute of Biotechnology \& Genetic Engineering, University of Sindh, Jamshoro-Pakistan \\ 2. Key Laboratory of Tropical Biological Resources of Ministry of Education, School of Life and \\ Pharmaceutical Sciences, Hainan University, Haikou 570228-China \\ 3. Ministry of Education Key Laboratory for Ecology of Tropical Islands, College of Life Sciences, Hainan \\ Normal University, Haikou, Hainan 571158-China \\ *Corresponding author's email: m.rafiq@usindh.edu.pk \\ Citation \\ Mir Muhammad Nizamani, Muhammad Rafiq, Nazo Noor-ul-Ain, Syed Habib Ahmed Naqvi, Arif Hussain \\ Kaleri and Juma Gul. Effect of chemical mutagens on growth of Okra (Abelmoschus esculentus L. Moench). \\ Pure and Applied Biology. Vol. 9, Issue 1, pp1110-1117. http://dx.doi.org/10.19045/bspab.2020.90116
}

\begin{tabular}{llll}
\hline \hline Received: 22/10/2019 & Revised: 02/01/2020 & Accepted: 09/01/2020 & Online First: 25/01/2020 \\
\hline
\end{tabular}

\section{Abstract}

The purpose of the present study was to evaluate the effects of mutagens i.e. Ethyl methanesulfonate (EMS) and Sodium azide (SA) on the morphological growth of Okra. Seeds of two Okra varieties Subzpari and Pahuja were first pre-soaked in distilled water and then treated with 0.0 (Control), 0.1, 0.2 and $0.3 \%$ Sodium azide (SA) and Ethyl methanesulfonate (EMS) separately. The results showed that the germination rate was significantly decreased with increased lethality (\%) and mutation frequency (\%) in $\mathrm{M}_{1}$ of both varieties with increasing concentrations of EMS and SA against control. The results showed that different concentrations of EMS and SA affected morphological attributes of both okra varieties as the increase of mutagen concentration showed variable results in $\mathrm{M}_{1}$ generation compared with control, but $\mathrm{M}_{2}$ generation showed useful improvement in various traits. Such as the $\mathbf{M}_{2}$ generation of Subs pari from $0.1 \%$ SA treatment showed a decrease in flowering time while an increase in the number of fruits per plant, fruit size, seeds yield (g) per plant and 100 seeds weight.

Keywords: Ethyl methane sulfonate; Growth; Induced mutagenesis; Okra; Sodium azide

\section{Introduction}

Okra [Abelmoschus esculentus (L.) Moench, $2 \mathrm{n}=2 \mathrm{x}=130]$ is one of the important vegetables belongs to Malvaceae family and known by many names in different regions of the world as, Gumbo in the USA, ladyfinger in England, Quingombo in Spanish, Huang Giu Kui in China, Bhindi in India and Pakistan, Dherosh in Bangladesh. Okra plant is native to northern Africa from Ethiopia and Sudan. It is summer and rainy season crop and is widely cultivated from tropics to subtropics. Okra (Abelmoschus
esculentusL.) is probably an amphidiploid (allotetraploid) derived from Abelmoschus tuberculatus with $2 \mathrm{n}=58$ and Abelmoschus ficulneus (L.) Wight and Arn. ex Wight with $2 \mathrm{n}=72$ chromosomes. Another edible okra species Abelmoschus caillei (A. Chev.) is found in the Central and West Africa. There are strong indications that Abelmoschus caillei is amphidiploids with Abelmoschus esculentus being one of the parental species. The lowest chromosome number $2 \mathrm{n}=56$ reported in Abelmoschus angulosus whereas, the highest 
chromosome number $2 \mathrm{n}=196$ reported in Abelmoschus manihot var. Caillei [1,2].

Fresh Okra fruits are a good source of carbohydrates, proteins, oil, potassium, magnesium, calcium, iodine, vitamins A and $\mathrm{C}$, etc $[3,4]$. The Okra crop has many uses; fresh green pods are eaten as a vegetable, immature pods are fried, steamed, canned or pickled, stem and mature fruits are used in the paper industry. It is very useful about antiulcer, anticancer and hypoglycemic activities [5].

Mostly conventional breeding methods are employed for the improvement of crops and natural variability in the germplasm. This takes a long time to select genetic variability within local crops $[6,7]$. To overcome this situation, induced mutagenesis can be used as an alternative method to create variability in different quantitative traits. Mutations are sudden genetic changes in living cell DNA that is neither genetically isolated nor genetically recombined [8]. According to Drake and others [9], mutations occur in the eukaryotic genome as $10^{-8}$ base pair per generation. Mutations can be induced artificially by using physical and chemical mutagens. Induced mutations have been used as an important tool for the improvement of certain traits in the existing germplasm. After Muller [10] discovered the mutagenic effects of X-rays on the fly, induced mutations were used for plant breeding. Ethyl Methanesulfonate is a carcinogenic organic compound, a popular and powerful mutagen that produces random point mutations in the genomes through nucleotide substitutions [11,12].

Therefore, okra is of high nutritional value with medical applications and economic importance hence needs to improve the production, quality and quantity of fruit. Taking into account the importance of okra, the present study was done with the objectives of evaluating the germination and growth attributes of $\mathrm{M}_{1}$ and $\mathrm{M}_{2}$ generations okra through the treatment of sodium azide (SA) and ethyl methane sulfonate (EMS) under different concentrations.

\section{Materials and methods}

Seeds of two varieties of Okra (Pahuja and Subzpari) were obtained from registered seed companies, Hyderabad, Pakistan. The experiment was performed during the year 2015-16 at IBGE, University of Sindh, Jamshoro, Pakistan.

\section{Treatment of Okra seeds}

For chemical mutagenesis, $0.1 \%$ $(0.5 \mathrm{~g} / 50 \mathrm{ml}), 0.2 \%(1.0 \mathrm{~g} / 50 \mathrm{ml})$ and $0.3 \%$ $(1.5 \mathrm{~g} / 50 \mathrm{ml})$ solutions of ethyl methane sulfonate (ACROS) and sodium azide (ACROS) were prepared separately.

For each treatment, 250dry, healthy and uniform sized seeds of both okra varieties; Pahuja and Subzpari were initially presoaked in $100 \mathrm{ml}$ distilled water in the lab at room temperature for six hours to ensure complete hydration. After removing the excess water presoaked 60seeds of each Pahuja and Subzpari varieties were submerged in $50 \mathrm{ml}$ solutions containing sodium azide and ethyl methane sulfonate separately with shaking (70rpm) in the dark for 60 minutes at room temperature [13]. After chemical treatment, seeds were washed with tap water and were sown in pots (5 seeds/pot) containing 10kg of sand and clay (1:1 ratio). For control, untreated seeds were soaked in distilled water for seven hours. The experiment was repeated twice and the total 120 seeds were used for each treatment.

For $\mathrm{M}_{2}$ generation study, mature, dry and uniform seeds of each treatment and control obtained from $\mathrm{M}_{1}$ generation were grown in pots under the same soil conditions as in $\mathrm{M}_{1}$ generation. The experiment was performed two times, thus a total 120 seeds for each treatment in the $\mathrm{M}_{2}$ generation study.

The mutagenic effect of ethyl methanesulfonate (EMS) and sodium azide (SA) on $\mathrm{M}_{1}$ and $\mathrm{M}_{2}$ generations of both okra varieties was assessed. Various growth attributes including germination (\%), shoot and root lengths, stem diameter, number of branches, flowering time, number of fruits, 
fruit length, seeds per fruit and 100 seeds weight were observed.

The germination of seeds was observed after every week for three weeks and the germination percentage was calculated after three weeks by the formula as follows:

Germination $(\%)=$ Number of seeds germinated $\times 100$

Total number of seeds sown

The survival of plants was noted after 30 days of sowing the lethality percentage was calculated as:

Lethality $(\%)=\underline{\text { Number of plants diedx }} 100$

Total number of seeds germinated

The mutation frequency of ethyl methane sulfonate and sodium azide was calculated according to the reported method [14] as;

Mutation frequency $(\%)=\underline{\text { Viable mutants observed }(\mathrm{V})}$ Total plants studied $(\mathrm{P})$

The shoot length of each plant was measured after 30 days of sowing and expressed in $\mathrm{cm}$ while root length was measured after harvesting of fruits and expressed in $\mathrm{cm}$. The shoot diameter was measured on maturity time while number of branches was counted at maturity. The fruit size was measured at maturity, number of fruit per plant, number of seeds per fruit and 100 seeds weight was determined.

The experiment was performed according to the Randomized Complete Block Design (RCBD) manner. The collected data were expressed as the mean of triplicates \pm standard deviation (SD) which was calculated.

$S=\sqrt{\frac{1}{N-1} \sum_{i=1}^{N}(x i-\bar{x})} 2$

$\mathrm{S}=$ sample standard deviation

$\mathrm{N}=$ the number of observations

$x i=$ the observed values of a sample item

$\bar{x}=$ the mean value of the observations

\section{Results and discussion}

Germination of seeds is a key parameter used to evaluate the impact of the mutagen on plants. The inhibition of seed germination after the treatment of seeds with various mutagens is a very effective method to study the effects of mutagens on plants.

The germination of seeds was found to be the highest in control plants as compared to other treated plants during $\mathrm{M}_{1}$ and $\mathrm{M}_{2}$ generations which showed that mutagenic treatments inhibited the germination in both varieties. The results revealed that germination was significantly reduced as the dose of mutagen was increased. The lowest germination response was noted in $M_{1}$ plants of Subs pri when seeds were treated with $0.3 \%$ of EMS and SA as $45 \%$ and $40 \%$ respectively compared to control which showed $90 \%$ germination (Table 1). Similarly,both varieties Subs pri and Puhja showed sensitivity to higher doses of mutagens as $38 \%$ and $40 \%$ lethality observed in $0.3 \%$ of SA and EMS respectively in Subs pri and $40 \%$ and $47 \%$ lethality in $0.3 \%$ SA and EMS treated $\mathrm{M}_{1}$ plants of Puhja. Similarly, the highest $\%$ of survived mutants was in $0.1 \%$ EMS and SA treated plants of Subspri and Puhja with $92 \%$ and $93 \%$ mutant frequency respectively (Table 1).

On the other hand, seed germination response was good in all seeds obtained from $\mathrm{M}_{1}$ plants which showed $59 \%$ to $75 \%$ germination response in $\mathrm{M}_{2}$ plants compared with control 84-88\% germination (Table 1). Similarly, $\mathrm{M}_{2}$ plants showed less lethality and mutant frequency than $\mathrm{M}_{1}$ plants. Seed germination is a significant trait for measuring the response of plants to mutagenic treatment [15]. As observed in the present study, Ettheret al.[16] also reported the promotion of biological parameters by low-dose SA and EMS. Contrary to our results, seed germination was reduced to all doses of sodium azide in Eruca sativa L [17] and in Helianthus annum [18]. Delays or inhibition of physiological activities including enzymatic activity, hormonal imbalance and mitotic activity essential for germination of seeds have explained the reduction in germination caused by mutagenesis $[17,19]$. The results revealed 
that there is a linear association between increased doses of mutagens (SA and EMS) and reduced germination of seeds. This was also reported in black gram [20], wheat [21] and Okra [22].

The shoot length in two okra varieties was observed to exhibit marginal differences in mutagens treated and control. The effect of EMS on shoot length of Subz pari was noted as a significant increase in shoot length $(17.2 \pm 2.1$ to $19.3 \pm 1.9 \mathrm{~cm})$ was observed in $0.1 \& 0.2 \%$ EMS treated $\mathrm{M}_{1}$ and $\mathrm{M}_{2}$ plants compared with control $(15.5 \pm 1.2 \mathrm{~cm})$. On the other hand, $0.3 \%$ SA treated $M_{1}$ and $M_{2}$ plants of Puhja showed a significant decrease in shoot length as $10.5 \pm 2.12$ and $10.76 \pm 2.5 \mathrm{~cm}$ respectively compared to control $(15.0 \pm 1.5 \mathrm{~cm})$ as shown in table 2.

Table 1. Effect of EMS and SA treatments on germination of Subz Pari and Pahuja varieties of Okra after 30 days of sowing

\begin{tabular}{|c|c|c|c|c|c|c|c|c|c|c|c|c|c|}
\hline \multirow{3}{*}{\multicolumn{2}{|c|}{ Treatments }} & \multicolumn{4}{|c|}{ Germination (\%) } & \multicolumn{4}{|c|}{ Lethality (\%) } & \multicolumn{4}{|c|}{ Mutation Frequency (\%) } \\
\hline & & \multicolumn{2}{|c|}{$\begin{array}{l}\text { Subz } \\
\text { Pari }\end{array}$} & \multicolumn{2}{|c|}{ Pahuja } & \multicolumn{2}{|c|}{$\begin{array}{l}\text { Subz } \\
\text { Pari }\end{array}$} & \multicolumn{2}{|c|}{ Pahuja } & \multicolumn{2}{|c|}{$\begin{array}{c}\text { Subz } \\
\text { Pari }\end{array}$} & \multicolumn{2}{|c|}{ Pahuja } \\
\hline & & $\overline{\mathrm{M}_{1}}$ & $\mathrm{M}_{2}$ & $\mathrm{M}_{1}$ & $\mathrm{M}_{2}$ & $\overline{M_{1}}$ & $\mathrm{M}_{2}$ & $\overline{M_{1}}$ & $\mathrm{M}_{2}$ & $\mathrm{M}_{1}$ & $\overline{\mathrm{M}_{2}}$ & $\mathrm{M}_{1}$ & $\mathrm{M}_{2}$ \\
\hline \multicolumn{2}{|c|}{ Control } & 90 & 88 & 83 & 84 & 2 & 1.89 & 2 & 0.99 & ND & ND & ND & ND \\
\hline \multirow{3}{*}{$\operatorname{EMS}(\%)$} & 0.1 & 80 & 85 & 73 & 78 & 7 & 1.94 & 6 & 2 & 92 & 98 & 93 & 97 \\
\hline & 0.2 & 58 & 78 & 66 & 65 & 15 & 2 & 20 & 2 & 84 & 97 & 80 & 97 \\
\hline & 0.3 & 45 & 72 & 53 & 59 & 38 & 6 & 40 & 5 & 61 & 93 & 59 & 94 \\
\hline \multirow{3}{*}{ SA (\%) } & 0.1 & 86 & 88 & 80 & 80 & 7 & 3 & 12 & 3 & 92 & 97 & 87 & 96 \\
\hline & 0.2 & 50 & 76 & 56 & 81 & 19 & 4 & 22 & 6 & 80 & 95 & 77 & 93 \\
\hline & 0.3 & 40 & 75 & 42 & 72 & 40 & 8 & 47 & 10 & 59 & 91 & 52 & 89 \\
\hline
\end{tabular}

Table 2. Effect of EMS and SA treatments on the shoot and root lengths, number of branches and stem diameter of Subz Pari and Pahuja varieties of Okra after 30 days against control Mean \pm S.D)

\begin{tabular}{|c|c|c|c|c|c|c|c|c|c|}
\hline \multirow{3}{*}{\multicolumn{2}{|c|}{ Treatments }} & \multicolumn{8}{|c|}{$M_{1}$ generation } \\
\hline & & \multicolumn{4}{|c|}{ Pahuja } & \multicolumn{4}{|c|}{ Subz Pari } \\
\hline & & $\begin{array}{l}\text { Shoot } \\
\text { Length } \\
(\mathrm{cm})\end{array}$ & $\begin{array}{l}\text { Root } \\
\text { Length } \\
(\mathrm{cm})\end{array}$ & $\begin{array}{c}\text { No of } \\
\text { branches/ } \\
\text { plant }\end{array}$ & $\begin{array}{c}\text { Stem } \\
\text { diameter } \\
(\mathrm{cm})\end{array}$ & $\begin{array}{l}\text { Shoot } \\
\text { Length } \\
(\mathrm{cm})\end{array}$ & $\begin{array}{l}\text { Root } \\
\text { Length } \\
(\mathrm{cm})\end{array}$ & $\begin{array}{c}\text { No of } \\
\text { branches/ } \\
\text { plant }\end{array}$ & $\begin{array}{c}\text { Stem } \\
\text { diameter } \\
(\mathrm{cm})\end{array}$ \\
\hline \multicolumn{2}{|c|}{ Control } & $14.8 \pm 1.5$ & $19.6 \pm 0.9$ & $10.0 \pm 1.9$ & $2.52 \pm 0.5$ & $15.8 \pm 1.2$ & $20.4 \pm 0.57$ & $11.4 \pm 0.5$ & $2.7 \pm 0.4$ \\
\hline \multirow{3}{*}{$\begin{array}{c}\text { EMS } \\
(\%)\end{array}$} & 0.1 & & 22.1 & 10.2 & $3.23 \pm$ & & .7 & & .5 \\
\hline & 0 & .1 & $20.7 \pm 1.2$ & 10.6 & $3.1 \pm 0.2$ & & 22.5 & & 2.8 \\
\hline & 0 & $2=$ & $18.2 \pm$ & $10^{5}$ & $2.4 \pm 0.7$ & $\overline{15.8}$ & $20.5 \pm$ & 1.6 & $2.3 \pm 0.3$ \\
\hline \multirow{3}{*}{$\begin{array}{c}\text { SA } \\
(\%)\end{array}$} & & 2 & $24.0 \pm 2.1$ & 10.8 & $2.9 \pm 0.6$ & $12.6 \pm 2.3$ & $20.4=$ & & $2.85 \pm 0.7$ \\
\hline & & $.4 \pm 1.2$ & $19.5 \pm 0.7$ & $9.5 \pm$ & $3.17 \pm 0.2$ & $11.9 \pm 2.7$ & $17.4 \pm 1.53$ & $10.8 \pm 1.6$ & $2 . .6 \pm 0.5$ \\
\hline & & $.5 \pm 2.1$ & & $9.4 \pm 1.2$ & $3.1 \pm 0.12$ & $12.8 \pm 1.3$ & $21.0 \pm 2.3$ & 10.6 & $2.08 \pm 0.4$ \\
\hline \multicolumn{10}{|c|}{$\mathrm{M}_{2}$ generation } \\
\hline \multicolumn{2}{|c|}{ Control } & & & 0.6 & $2.28 \pm 0.5$ & 15.5 & 121. & & 2.58 \\
\hline \multirow{3}{*}{$\begin{array}{c}\text { EMS } \\
(\%)\end{array}$} & & $15.9 \pm 1.3$ & $19.7 \pm 2.1$ & 11.1 & $2.5 \pm 0.6$ & $17.9 \pm 2.6$ & $22.5 \pm 0.7$ & 2.1 & 2.07 \\
\hline & & $14.2 \pm 2.1$ & $19.3 \pm 1.8$ & 10.8 & $2.43 \pm 0.6$ & $17.2 \pm 2.1$ & $21.15 \pm 1.2$ & .6 & $2.43 \pm 0.5$ \\
\hline & 0 . & $12.5 \pm 1.3$ & $17.8 \pm 2.7$ & & $2.3 \pm 0.7$ & $15.9 \pm 2.1$ & $18.8 \pm 0.92$ & $.5 \pm 0.7$ & $2.24 \pm 0.6$ \\
\hline \multirow{3}{*}{$\begin{array}{l}\text { SA } \\
(\%)\end{array}$} & 0 & $13.5 \pm 1.2$ & $21.5 \pm 1.4$ & $10.5 \pm 0.7$ & $2.69 \pm 0.4$ & $13.6 \pm 1.1$ & $19.67 \pm 2.08$ & $13.3 \pm 0.7$ & $2.53 \pm 0.4$ \\
\hline & 0 & $1.8 \pm 0.6$ & $18.2 \pm 0.7$ & $12.0 \pm 1.6$ & $2.5 \pm 0.6$ & $14.0 \pm 1.4$ & $20.3 \pm 2.4$ & $11.1 \pm 1.8$ & $2.28 \pm 0.5$ \\
\hline & 0.3 & $10.7 \pm 2.5$ & $17.8 \pm 1.4$ & $10.3 \pm 0.6$ & $2.5 \pm 0.5$ & $12.8 \pm 2.7$ & $16.67 \pm 2.1$ & $10.6 \pm 1.2$ & $2.31 \pm 0.4$ \\
\hline
\end{tabular}


The root length in two okra varietiesof EMS-treated plants increased slightly in $\mathrm{M}_{1}$ and $\mathrm{M}_{2}$, while the $\mathrm{SA}$ concentration was a little different in both $\mathrm{M}_{1}$ and $\mathrm{M}_{2}$ generations (Table 2). As the concentration of SA and EMS increases, the inhibitory effect of the mutagen decreased the root length. The decrease in root and shoot length is the effect of chemical mutagens on physiological systems [23]. The reduction in length of shoots and roots are due to mutagenesis has previously been studied in other plants [24]. Stimulation of shoot and root length was noted in lower doses of SA and EMS. It has also been noted in tomato that the seedling height is stimulated by low concentrations of mutagens [25]. Growth reduction is associated with auxin destruction, ascorbic acid changes, physiological and biochemical interference [22].

EMS and SA also affected the number of branches in Okra varieties under study compared to control plants. The maximum number of branches was noted in the $\mathrm{M}_{2}$ generations, with EMS being $0.1 \%$, while the Puhja variety had a slightly different response in $0.1,0.2$ and $0.3 \%$ of EMS in $\mathrm{M}_{1}$, while in the $\mathrm{M}_{2}$ generation. The maximum number of branches was noted with $0.1 \%$ and $0.2 \%$ EMS. For both of the $\mathrm{M}_{1}$ and $\mathrm{M}_{2}$ generations, SA showed almost similar results compared to control (Table $2)$. These results are similar to those reported by Biswas et al. [26] where the control plants produced significantly fewer branches than the mutagen in Trigonella species. The results are shown in (Table 2), the maximum shoot diameter was recorded in $0.1 \%$ of EMS treated plants. In the case of SA observed maximum diameter in $0.1 \%$ SA treated plant of Puhja compared to control plants when treated with SA and EMS, sabz pari variety shows a reduced diameter stem.

The results showed in table 3 revealed that as the concentration of the mutagens (EMS and SA) increased, the number of days of first flowering decreased. The effect of a higher dose of mutagens on flowering was also reported in urdbean [27] and garlic [28].The number of fruits/plants is shown in table 3. The results showed that the maximum number of fruits $(23.0 \pm 1.1$ and $21.0 \pm 1.4$ ) was developed from $0.2 \%$ and $0.1 \%$ of EMS exposure in Puhja compared with control $(15.0 \pm 1.2)$. An increase in number of fruits was noted due to 0.1 and $0.2 \%$ levels of EMS and $0.1 \%$ SA. Similar results were also obtained in cowpea [29]. The promotion of biological parameters by EMS and low-dose gamma-rays was previously reported in Vicia faba L. and Cicer arietinum $[16,30]$.

The results show that the effects of the two mutagenesis treatments are different and the varieties are diverse and passed down from generation to generation. According to results (Table 3), all mutagenic exposures of EMS and SA reduced the fruit size in M1 compared with control. This decrease in fruit size was significant in higher concentrations $(0.2$ and $0.3 \%)$ of EMS and SA. The minimum fruit length $(8.3 \pm 1.9 \mathrm{~cm})$ was observed in $0.3 \% \mathrm{SA}$ treated Pahuja. However, an increase in fruit length was observed in two treatments in $\mathrm{M}_{2}$ generation treated with $0.1 \%$ mutagen. The maximum fruit size $(12.5 \pm 1.1 \mathrm{~cm})$ was observed in $\mathrm{M}_{2}$ plants previously treated with $0.1 \%$ EMS compared with control $(11.5 \pm 0.3 \mathrm{~cm})$ in Subs pari. Benke [28] also reported changes in garlic plants treated with gamma rays. Our results are not in agreement with Goyal et al. [27] who reported a gradual increase in fruit size with increasing concentrations of DES and EMS in urdbean.

The result showed (Table 3) that the total number of seeds per fruit for each chemical treatment was variable by variety and generation. An increased seed yield $(29.6 \pm 1.2 \mathrm{~g})$ per plant was noted in $0.1 \%$ SA treated $\mathrm{M}_{2}$ plants of Subs pari variety as against $25.8 \pm 0.4 \mathrm{~g}$ in control while the minimum seed yield $(17.8 \pm 0.8 \mathrm{~g})$ was observed in $\mathrm{M}_{2}$ plants of Subs pari treated with $0.3 \%$ EMS. This variability in yield of Okra seeds per plant was also reported by other researchers $[31,32]$. 
Table 3.Effect of EMS and SA treatments on different yield parameters of Subz Pari and Pahuja varieties of Okra (Mean \pm S.D)

\begin{tabular}{|c|c|c|c|c|c|c|c|c|c|c|c|}
\hline \multirow{3}{*}{\multicolumn{2}{|c|}{ Treatments }} & \multicolumn{10}{|c|}{$M_{1}$ generation } \\
\hline & & \multicolumn{5}{|c|}{ Pahuja } & \multicolumn{5}{|c|}{ Subz Pari } \\
\hline & & $\begin{array}{c}\text { Days to } \\
\text { flowerin } \\
\mathrm{g}\end{array}$ & $\begin{array}{l}\text { No of } \\
\text { fruits / } \\
\text { plant }\end{array}$ & $\begin{array}{l}\text { Fruit } \\
\text { size/ } \\
\text { length } \\
(\mathrm{cm})\end{array}$ & $\begin{array}{c}\text { Seeds } \\
\text { yield / } \\
\text { plant (g) }\end{array}$ & $\begin{array}{c}100 \\
\text { Seeds } \\
\text { weight } \\
(\mathrm{g})\end{array}$ & $\begin{array}{c}\text { Days to } \\
\text { flowerin } \\
\mathrm{g}\end{array}$ & $\begin{array}{l}\text { No of } \\
\text { fruits / } \\
\text { plant }\end{array}$ & $\begin{array}{l}\text { Fruit } \\
\text { size/ } \\
\text { length } \\
(\mathrm{cm})\end{array}$ & $\begin{array}{c}\text { Seeds } \\
\text { yield / } \\
\text { plant (g) }\end{array}$ & $\begin{array}{c}100 \text { seeds } \\
\text { weight } \\
(\mathrm{g})\end{array}$ \\
\hline \multicolumn{2}{|c|}{ Control } & 60 & $15.0 \pm 1.2$ & $10.3 \pm 0.4$ & $27.5 \pm 0.6$ & 5.86 & 52 & $13.5 \pm 1.2$ & $11.7 \pm 0.5$ & $26.0 \pm 0.5$ & 6.3 \\
\hline \multirow{3}{*}{$\begin{array}{c}\text { EMS } \\
(\%)\end{array}$} & 0.1 & 58 & $21.0 \pm 1.4$ & $8.8 \pm 0.5$ & $20.6 \pm 1.8$ & 5.38 & 46 & $14.0 \pm 0.5$ & $10.4 \pm 0.5$ & $20.5 \pm 1.5$ & 5.3 \\
\hline & 0.2 & 46 & $23.0 \pm 1.1$ & $8.7 \pm 1.2$ & $18.5 \pm 2.1$ & 5.16 & 43 & $13.3 \pm 0.7$ & $9.7 \pm 1.1$ & $19.4 \pm 1.8$ & 5.28 \\
\hline & 0.3 & 47 & $14.5 \pm 0.7$ & $8.9 \pm 1.1$ & $21.0 \pm 2.2$ & 5.02 & 32 & $10.5 \pm 0.7$ & $7.5 \pm 1.2$ & $18.3 \pm 1.6$ & 4.89 \\
\hline \multirow{3}{*}{$\begin{array}{c}\text { SA } \\
(\%)\end{array}$} & 0.1 & 57 & $16.5 \pm 2.1$ & $8.6 \pm 0.5$ & $24.3 \pm 1.2$ & 5.42 & 54 & $16.0 \pm 1.1$ & $11.4 \pm 0.6$ & $27.3 \pm 1.2$ & 5.9 \\
\hline & 0.2 & 52 & $10.0 \pm 1.2$ & $9.5 \pm 1.2$ & $28.2 \pm 1.5$ & 5.04 & 48 & $13.5 \pm 0.7$ & $9.7 \pm 1.6$ & $22.2 \pm 1.5$ & 5.16 \\
\hline & 0.3 & 49 & $9.7 \pm 1.5$ & $8.3 \pm 1.9$ & $19.1 \pm 2.2$ & 4.94 & 42 & $12.2 \pm 2.1$ & $8.5 \pm 1.1$ & $18.3 \pm 1.6$ & 5.01 \\
\hline \multicolumn{12}{|c|}{$\mathrm{M}_{2}$ generation } \\
\hline \multicolumn{2}{|c|}{ Control } & 59 & $17.5 \pm 2.1$ & $10.6 \pm 0.4$ & $28.8 \pm 0.4$ & 5.81 & 50 & $12.8 \pm 0.4$ & $11.5 \pm 0.3$ & $25.8 \pm 0.4$ & 6.25 \\
\hline \multirow{3}{*}{$\begin{array}{c}\text { EMS } \\
(\%)\end{array}$} & 0.1 & 30 & $20.5 \pm 1.3$ & $11.7 \pm 0.5$ & $26.3 \pm 1.4$ & 6.97 & 26 & $18.1 \pm 1.1$ & $9.4 \pm 0.2$ & $24.5 \pm 1.1$ & 7.35 \\
\hline & 0.2 & 33 & $20.0 \pm 0.5$ & $9.7 \pm 0.5$ & $25.2 \pm 1.3$ & 6.35 & 24 & $19.4 \pm 1.3$ & $9.5 \pm 0.4$ & $22.2 \pm 0.9$ & 6.2 \\
\hline & 0.3 & 23 & $16.5 \pm 0.7$ & $10.7 \pm 0.6$ & $27.0 \pm 0.6$ & 6.56 & 24 & $11.7 \pm 1.2$ & $8.4 \pm 0.5$ & $17.8 \pm 0.8$ & 5.72 \\
\hline \multirow{3}{*}{$\begin{array}{l}\text { SA } \\
(\%)\end{array}$} & 0.1 & 27 & $17.0 \pm 0.5$ & $10.7 \pm 0.4$ & $28.9 \pm 1.5$ & 7.05 & 33 & $16.5 \pm 1.04$ & $12.5 \pm 1.1$ & $29.6 \pm 1.2$ & 7.74 \\
\hline & 0.2 & 22 & $14.5 \pm 0.7$ & $11.2 \pm 0.7$ & $28.3 \pm 0.4$ & 7.01 & 23 & $16.1 \pm 1.3$ & $10.6 \pm 0.8$ & $28.4 \pm 0.4$ & 7.62 \\
\hline & 0.3 & 25 & $12.1 \pm 0.5$ & $8.9 \pm 1.1$ & $24.5 \pm 1.1$ & 6.56 & 26 & $11.7 \pm 1.2$ & $8.8 \pm 0.4$ & $20.1 \pm 1.1$ & 6.54 \\
\hline
\end{tabular}

EMS and SA treatments also affected the seed weight of both okra varieties. The 100 seeds of each treatment were randomly collected and weighed. The results showed that there was a slight decrease in 100 seeds weight on different concentrations of EMS and $\mathrm{SA}$ in the $\mathrm{M}_{1}$ generation against control (Table 3). But $\mathrm{M}_{2}$ showed different results then $M_{1}$ generation as an increase in 100 seeds weight was noted in $\mathrm{M}_{2}$ generation against control. The maximum seeds weight (7.74 g) was observed in Subs pari fruits of $\mathrm{M}_{2}$ plants treated with $0.1 \% \mathrm{SA}$ against control $(6.25 \mathrm{~g})$. In cowpea reported similar results observed by [29].Effecter mutagens have been found to reduce the quantitative traits of soybeans [33]. The obtained variability in all levels of mutagenesis observed for various traits revealed a range of improvements [34].

\section{Conclusion}

Okra is an important multipurpose vegetable rich in carbohydrates, proteins, minerals, vitamins, etc. Unfortunately, very little work is being done on this crop in Pakistan. The results showed that different concentrations of EMS and SA affected morphological attributes of both okra varieties as the increase of mutagen concentration showed variable results regarding morphological attributes in $\mathrm{M}_{1}$ generation against control, but $\mathrm{M}_{2}$ generation showed useful improvement in various traits. Such as the $\mathrm{M}_{2}$ generation of Subs pari from $0.1 \%$ SA treatment showed a decrease in flowering time while an increase in the number of fruits per plant, fruit size, seeds yield (g) per plant and 100 seeds weight. It is suggested that M3 generation of Okra varieties may be cultivated on different locations and morphological attributes may be further evaluated.

\section{Authors' contributions}

Conceived and designed the experiments: M Rafiq, Performed the experiments: N Noor-ul-Ain \& MM Nizamani, Analyzed the data: AH Kaleri, J Gul \& MM Nizamani, Contributed materials/ analysis/ tools: M Rafiq \&SHA Naqvi, Wrote the paper: MM Nizamani.

\section{References}

1. Singh HB \& Bhatnagar A (1975). Chromosome number in okra from 
Ghana. Indian J Gen Pl Breed 36:2627.

2. Siemonsma JS (1982). West African okra morphological and cytological indications for the existence of a natural amphiploid of Abelmoschus esculentus (L.) Moench and $A$. Manihot (L.) Medikus. Euphytica 31(1):241-52.

3. Norman JC (1992). Tropical Vegetable Crops. Arthur H. Stockwell Ltd., Devon

4. Das S, Nandi G \& Ghosh LK (2019). Okra and its various applications in Drug Delivery, Food Technology, Health Care and Pharmacological Aspects-A Review. Int J Pharm Sci 11(6): 2139-2147.

5. Atodariya U, Upadhyay S \& Upadhyay U (2013). Anti-ulcer activity of Okra mucilage. Int J Phytopharm 4(1): 3439.

6. Nizamani MM, Nizamani FG, Rind RA \& Khokhar AA (2019). Assessment of genetic variability and heritability estimates in $\mathrm{F} 2$ populations of bread wheat (Triticum aestivum L.). Discov Agri 5: 177-188.

7. Nizamani MM, Nizamani FG, Rind RA, Khokhar AA, Mehmood A \& Nizamani M (2020). Heritability and genetic variability estimates in F3 populations of bread wheat (Triticum aestivum L.). Pure Appl Boil 9(1):352368.

8. Van Harten AM (1998). Mutation Breeding: Theory and Practical Applications. Cambridge University Press, Cambridge.

9. Drake JW, Charlesworth B, Charlesworth D \& Crow JF (1998). Rates of Spontaneous Mutation. Genetics 148: 1667-1686.

10. Muller H (1928). The production of mutations by X-rays. Proceedings of the National Academy of Sciences of the United States of America 14: 714.

11. Minocha JL \& ArnasonTJ (1962). Mutagenic effectiveness of ethyl methane sulphonate in barley. Nature 196: 499.

12. Okagaki RJ, Neffer MG \& WesslerSR (1991). A deletion common totwo independently derived waxy mutations of maize. Genetics 127: 425-431.

13. Koornneef M, Dellaert LWM \& Van der Veen JH (1982). EMS-and radiation-induced mutation frequencies at individual loci in Arabidopsis thaliana (L) Heynh. Mutat Res 93(1):109-123.

14. Roychowdhury R \& Tah J (2011). Chemical mutagenic action on seed germination and related agro-metrical traits in $\mathrm{M}_{1}$ Dianthus generation. Curr Bot 2(8):19-23.

15. Ashadevi R, Sarika K, Sekhon H, Chamroy $\mathrm{T} \&$ Chattopadhyay SB (2019). Mutation frequency, efficiency and effectiveness of gamma rays and ethyl methane sulphonate in okra. Plant Arch 19(2): 2785-2791.

16. Etther Y, Gahukar SJ, Akhare A, Patil AN, Jambhulkar SJ \& Gawande M (2019). Mutagenic effectiveness and efficiency of gamma rays, Ethyl methyl sulfonate and their synergistic effects in Pigeonpea (Cajanus cajan L.). J Pharmacogn Phytochem 8(3): 489-493.

17. Khan S \& Al-Qurainy F (2009). Mutagenic effect of sodium azide on seed germination of Eruca sativa (L.). Aus. J. Basic Appl Sci 3: 3081-3087.

18. Mostafa GG (2011). Effect of sodium azide on the growth and variability induction in Helianthus L. Int J Plant Breed Genet 5: 76-85.

19. Ramkumar R \& Dhanavel D (2019). Effect of Ethyl Methane Sulphonate (EMS) on Germination Behaviour and Seedling Survival of Panicum sumatrense Roth Ex Roemers \& Schultz. J Guj Res Soc 21(15): 160164.

20. Yasmin K, Arulbalachandran D, Soundarya V\& Vanmathi S (2019). Effects of gamma radiation $(\gamma)$ on biochemical and antioxidant properties 
in black gram (Vigna mungo L. Hepper). Int J Radiat Biol 95(8):1-9.

21. Olaolorun BM, Shimelis HA, Mathew I \& Laing MD (2019). Optimising the dosage of ethyl methanesulphonate mutagenesis in selected wheat genotypes. Afr J Plant Soil 36(5): 357366.

22. Singh AK, Singh KP \& Singh RB (2000). Seedling injury, reduced pollen and ovule fertility and chlorophyll mutations induced by gamma rays and EMS in okra Abelmoschus esculentus (L.) Moench. Veg Sci 27: 42-44.

23. Sato M \& Gaul H (1967). Effect of ethyle methane sulphonate on the fertility of barley. Radiat Bot 7: 7-15.

24. Uma MS \& Salimath PM (2001). Effects of ionizing radiations on germination and emergence of cowpea seeds. Kerala J Agric Res 14(4): 10631064.

25. Aliyu H \& Adamu A (2007). The effect of diethyl sulphate on some quantitative traits of tomato (Lycopersicon esculentum Mill). Sci World J 2: 1-4.

26. Biswas AK \& Datta AK (1988). Induced mutation in two Trigonella species. Bangl J Bot17: 211-214.

27. Goyal S, Wani MR \& Khan S (2019). Gamma Rays and Ethyl Methanesulfonate Induced Early Flowering and Maturing Mutants in Urdbean (Vigna mungo (L.) Hepper). Int J Bot 15: 14-21.

28. Benke AP, Dukare S, Jayaswall K, Yadav VK \& Singh M (2019). Determination of proper gamma radiation dose for creating variation in Indian garlic varieties. Indian J Tradit Knowl 18(3): 547-552.

29. Gnanamurthy S, Mariyammal S, Dhanavel D\& Bharathi T (2012). Effect of gamma rays on yield and yield components characters R3 generation in cowpea (Vigna unguiculata (L.) Walp.). Int. J. Res. Plant Sci 2(2): 39-42.

30. Kumar S, Katna G \& Sharma N (2019). Mutation breeding in chickpea. $\mathrm{Adv} P \mathrm{Pl}$ Agric Res 9(2): 355-362.

31. Vwioko ED, El-Esawi MA, Imoni ME, Al-Ghamdi AA, Ali HM, El-Sheekh MM, Abdeldaym EA \& Al-Dosary MA (2019). Sodium Azide Priming Enhances Water logging Stress Tolerance in Okra (Abelmoschus esculentus L.). Agron 9(11):679.

32. Aminu Y, Maryam MG \& Kabiru SA (2019). Hormonal Response of Gibberellin (Ga3), Grafting and Seasonal Variations on Growth and Yield Parameters on Okra (Abelmoschus esculentus). Amer Int J Biol Sci 1(2): 33-39.

33. Silva LCC, Mota LM, Fonseca LABV, Bueno RD, Piovesan ND, Fontes EPB \& Dal-Bianco M (2019). Effect of a mutation in Raffinose Synthase 2 (GmRS2) on soybean quality traits. Crop Breed Appl Biotechnol 19(1): 6269.

34. Jain SM (2010). Mutagenesis in crop improvement under the climate change. Rom Biotech Lett 15(2): 88106. 